\title{
BREWER'S BLACKBIRDS SUCCESSFULLY NEST IN BIRDHOUSE
}

\author{
JEAN BANCROFT, 306-200 Tuxedo Avenue, Winnipeg, Manitoba. R3P OR3
}

In early spring flocks of Brewer's Blackbirds appear about our open farmlands, towns and cities. More recently they seem to be flourishing because we have never had such large numbers remain at Whytewold, where our summer cottage is located (at the south end of Lake Winnipeg). In fact, during the summer of 1985, cottagers began to feel that so many black-looking birds, including Common Grackles, Red-winged Blackbirds and Brown-headed Cowbirds, were an ominous sign.

Not far from our property a new cottage was being built and on 5 June I went to investigate. In the midst of all the construction a pair of Brewer's Blackbirds had chosen to nest in one side of a twocompartment, green nest box $3 \mathrm{~m}$ from the side of the new house. The box was approximately $30 \times 20 \times 17.5 \mathrm{~cm}$ and was attached to the trunk of a Manitoba Maple, $3.6 \mathrm{~m}$ off the ground; the entrance holes had been enlarged unevenly, presumably by a squirrel, to $6.25 \mathrm{~cm}$, and a nail served as a stoop.

Two young were seen at the entrance of the nest box moments before an adult came with food. The next day the alarmed male flew about giving loud repetitive "chucks." When I drew away a little, the female came with food and I saw three young. During the next few days both male and female fed the young. On 7 June the parent birds were anxious to feed the young but were hesitant due to the presence of myself and the property owner; they kept flying in and around the trees with a cacophony of "chucks." Several other Brewer's appeared at the same time and joined in the chorus. After the owner left, the male came with a winged insect, and put its beak right down the young one's throat.

At 0750 on 10 June both male and female flew around giving the usual loud calls; they would not go near the nest box. The three young, crowded in their small compartment, gave quiet "chucks." In the afternoon one fledgling came over halfway out, squawking loudly, but the parents did not heed. Then it pulled itself back into the box, exercised its wings, and again nearly came out. Later there were, above the nest box, two stub-tailed fledglings in the leafy branches of the tree. The third fledgling still had not come out after a half hour, and was still in the nest box at a later check.

There are apparently only three previous records of members of the blackbird family (Icteridae) nesting in nest boxes. Two were of Red-winged Blackbirds and one a Common Grackle (pers. comm., R.W. Nero, 1986). Thus, this is evidently the fourth record for an icterid and the first for the Brewer's Blackbird. 